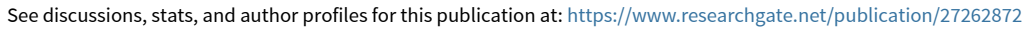

\title{
Are Rhodophyceae a dietary component for deep-sea holothurians?
}

Article in Journal of the Marine Biological Association of the UK · April 2002

DOI: $10.1017 /$ S0025315402005556 - Source: OAI

CITATIONS

7

4 authors, including:

Solveig Irena Bühring

Universität Bremen

129 PUBLICATIONS 657 CITATIONS

SEE PROFILE

Some of the authors of this publication are also working on these related projects:

CUSCO (Coastal Upwelling System in a Changing Ocean) View project

Deepwater ichthyofauna communities of seamounts from the eastern Atlantic Ocean View project

\section{READS}

42

Bernd Christiansen

University of Hamburg

53 PUBLICATIONS 767 CITATIONS

SEE PROFILE 


\title{
Are Rhodophyceae a dietary component for deep-sea holothurians?
}

\author{
S.I. Bühring $*^{\ddagger}$, R. Koppelmann ${ }^{\dagger}$, B. Christiansen ${ }^{\dagger}$ and H. Weikert ${ }^{\dagger}$ \\ *Max-Planck-Institut für Marine Mikrobiologie, Celsiusstraße 1, 28359 Bremen, Germany. ${ }^{\dagger}$ Institut für Hydrobiologie und Fischerei- \\ wissenschaft, Zeiseweg 9, 22765 Hamburg, Germany. ${ }^{\ddagger}$ Corresponding author, e-mail: sbuehrin@mpi-bremen.de
}

\begin{abstract}
Eicosatetraenoic acid (20:4(n-6)), a polyunsaturated fatty acid (PUFA), was found in deep-sea holothurians at a depth of nearly $5000 \mathrm{~m}$ in the temperate north-east Atlantic. It has been suggested that deep-sea animals may be able to synthesize this compound de novo. Since this fatty acid is typical of Rhodophyceae, which has previously been found incorporated in gelatinous material captured in the deep sea, an alternative origin of this fatty acid in the deep-sea holothurians is proposed.
\end{abstract}

The sedimentation of particulate organic matter (POM) to the sea-floor is subject to seasonal variations coupled to the productivity cycle of the phytoplankton. Billett et al. (1983) discovered a rapid seasonal deposition of phytodetritus to the deep-sea floor in the temperate North Atlantic Ocean. Large and fast sinking aggregates are the dominant mechanisms transporting organic matter into the deep sea, and they are important for the nutrition of the deep-sea community. Occasionally, large faecal mats from salps and remains of dead and decaying organisms, together with phytoplankton spring bloom material, form large aggregates of gelatinous material that can be sampled by closing nets at bathyal and abyssal depths (see Koppelmann, 1994).

Holothurians, the dominant epibenthic megafauna in many deep-sea areas, often feed on the superficial sediment and are therefore important in the degradation of organic material. In the present paper two investigations demonstrate that there is an indication that deep-sea holothurians may occasionally use Rhodophyceae as a food source.

The holothurians were sampled in August 1998 during cruise M42/2 of RV 'Meteor' to the Porcupine Abyssal Plain (PAP, $48^{\circ} 50^{\prime} \mathrm{N} 16^{\circ} 30^{\prime} \mathrm{W}$ ) in the north-east Atlantic. The water depth at this site is $\sim 4850 \mathrm{~m}$. The animals were caught with an epibenthic sledge. After recovery of the sledge, the gonads of Oneirophanta mutabilis and Psychropotes longicauda were dissected and stored at $-80^{\circ} \mathrm{C}$ for seven months. In order to avoid oxidation processes in the vials, the air was displaced by nitrogen. The lipids were extracted with a mixture of dichlormethane and methanol (2:1, v:v). For the gas chromatographic analysis of the fatty acid composition, an aliquot of the extracted samples was converted into methylesters by transesterification with $3 \%$ concentrated sulphuric acid in methanol for $4 \mathrm{~h}$ at $80^{\circ} \mathrm{C}$. After extraction with hexane, $1 \mu \mathrm{l}$ was injected into a Chrompack CP 9000 gasliquid chromatograph (column $30 \mathrm{~m} \times 0.25 \mathrm{~mm}$; film thickness: $0.25 \mu \mathrm{m}$; liquid phase: DB-FFAP (Durabond ${ }^{\mathbb{R}}$-Free Fatty Acid Phase)). The methylesters were identified with standard mixtures and quantified with nonadecanacidmethylester as an internal standard. $\delta^{13} \mathrm{C}$ values of the fatty acids were measured using a GG-C-IRMS (Finnigan MAT) relative to the PDB standard.

The most abundant fatty acids in the gonads of $O$. mutabilis and P. longicauda were 20:4(n-6) together with 20:5(n-3) (Figure 1). These polyunsaturated fatty acids (PUFAs) are usually components of the phospholipids which increase the fluidity of the cell membranes (Sargent \& Falk-Petersen, 1981). This is especially important for deep-sea organisms due to the high pressure and low temperature conditions of their environment. The same fatty acid composition was found in shallow water holothurians, but deep-sea species possess greater proportions of unsaturated fatty acids than shallow-living species (Cossins \& Macdonald, 1986). The PUFAs are essential dietary components of marine animals, and their production has been conventionally considered to be supported by algae only (Sargent et al., 1993). The major algae groups differ significantly in their fatty acid composition: the planktonic diatoms and dinoflagellates contain large concentrations of the (n-3) PUFAs, while the (n-6) PUFAs are typical for littoral benthic algae. The shallow water members of the holothurians can feed directly on benthic littoral algae, but in sediments at abyssal depths the concentrations of polyunsaturated fatty acids are generally low (Santos et al., 1994).

Our identification of 20:4(n-6) in holothurians from nearly $5000 \mathrm{~m}$ depth at a remote ocean site is in accordance with analyses of Ginger et al. (2000) who found the same dominance of the polyunsaturated fatty acids 20:4(n-6) and 20:5(n-3) in $O$. mutabilis and $P$. longicauda and other deep-sea holothurians from the same region. These authors suggested that the animals may be able to biosynthesize these compounds de novo and thus belong to the very rare number of species which are able to synthesize these PUFAs. Our preliminary results of the $\delta^{13} \mathrm{C}$ composition gives evidence that the $20: 4(n-6)$ is of marine plant origin, because of the low $\delta^{13} \mathrm{C}$ value of -22.8 psu and the difference of more than 3 psu to fatty acids that are normally synthesized de novo by marine animals, e.g. -19.4 psu of 18:1 (n-9).

It is well-known that benthic algae can be torn off by wave activity and transported over long distances by surface currents (Hoek, 1987). Another possible source is the Sargasso Sea, where Woelkerling (1975) found 33 species of Rhodophyceae beside Sargassum. We have indirect evidence that the PUFAs may, indeed, result from a Rhodophycean food.

Filamentous Rhodophyceae (Figure 2) were found incorporated as an intrinsic element of gelatinous detrital material in the deep sea. The material was caught in a fresh condition in April/May 1988 at PAP and at the nearby BIOTRANS site (Koppelmann, 1994) using a MOCNESS (Multiple Opening and Closing Net and Environmental Sensing System) with $333-\mu \mathrm{m}$ mesh aperture. Although we cannot exclude that the algae were incorporated in the flakes by shearing activity in the nets, they were certainly captured in the deep sea.

The appearance of filamentous algae in the deep sea may happen only occasionally, but it is possible that the holothurians do not depend on a frequent sedimentation of Rhodophyceae. 


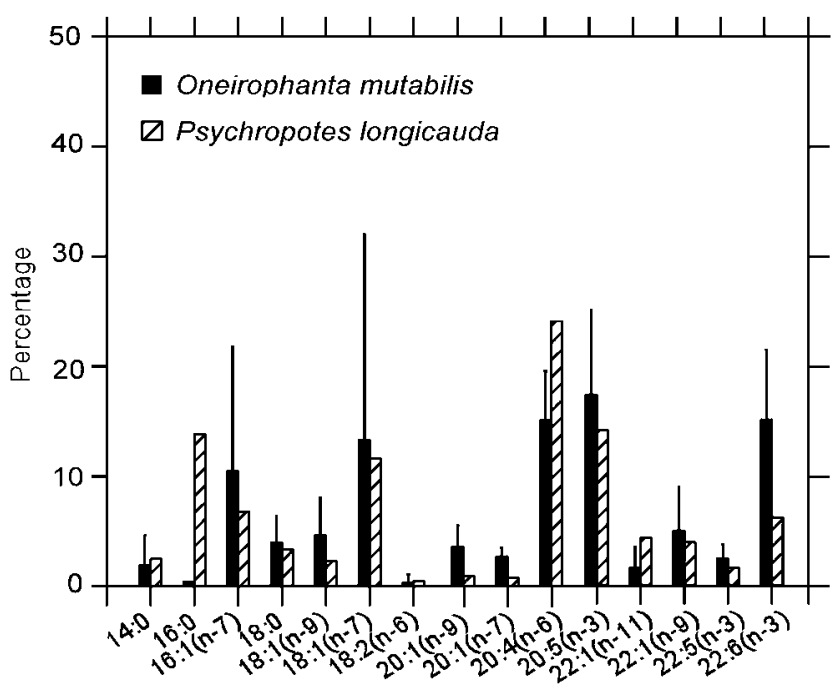

Fatty acid

Figure 1. Fatty acid composition of Oneirophanta mutabilis and Psychropotes longicauda.

Holothurians might be able to use sporadic events and store 20:4(n-6) over a long period since phospholipids normally are not used to gain metabolic energy. We do not reject the hypothesis that holothurians are able to synthesize the polyunsaturated fatty acids de novo; however, our results give some indication that Rhodophyceae are a possible additional source of fatty acids for deep-sea holothurians.

We thank the officers and crew of the RV 'Meteor' for their skilful assistance. The analysis of fatty acids was made possible at the Alfred-Wegener-Institute, Bremerhaven, by Dr G. Kattner. Dr M. Graeve gave very helpful advice for the analysis of the lipids. Professor L. Kies kindly helped in identifying the algae. We are also grateful to Dr M. Elvert for his help with the isotopic analysis. The investigations were funded by the BMBF (MFU 0544/9), the DFG (We 695/14-1) and the EU (MAS3-CT 950018).

\section{REFERENGES}

Billett, D.S.M., Lampitt, R.S., Rice, A.L. \& Mantoura, R.F.C., 1983. Seasonal sedimentation of phytoplankton to the deep-sea benthos. Nature, London, 302, 520-522.

Cossins, A.R. \& Macdonald, A.G., 1986. Homeoviscous adaptation under pressure. III. The fatty acid composition of liver mitochondrial phospholipids of deep-sea fish. Biochimica et Biophysica Acta, 860, 325-335.

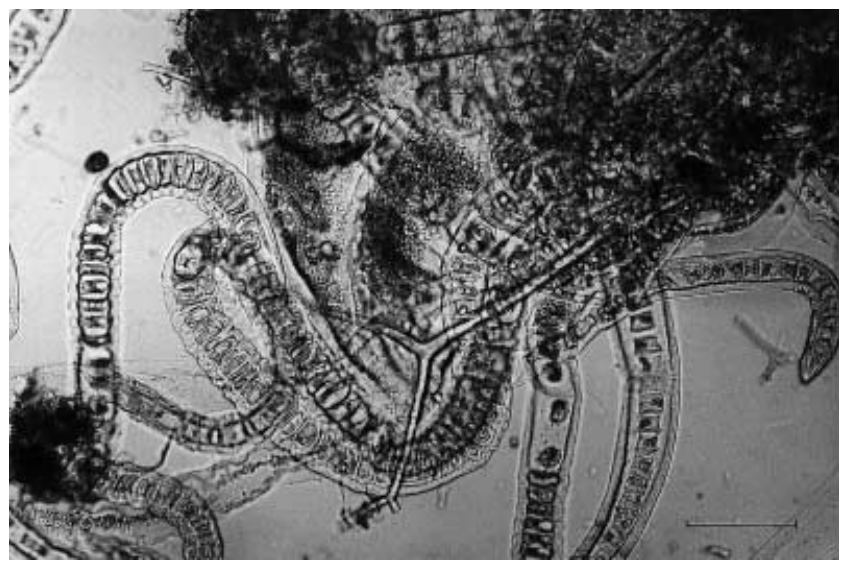

Figure 2. Filamentous Rhodophyceae found in detrital material from the deep sea. The bar in the lower right hand corner indicates a distance of $100 \mu \mathrm{m}$. Coordinates $47^{\circ} 15^{\prime} \mathrm{N} 19^{\circ} 30^{\prime} \mathrm{W}$; date of sampling, 10 May 1988; sampling depth, 2750-3000 m; total water depth, $4550 \mathrm{~m}$.

Ginger, M.I., Santos, V.L.C.S. \& Wolff, G.A., 2000. A preliminary investigation of the lipids of abyssal holothurians from the north-east Atlantic Ocean. Fournal of the Marine Biological Association of the United Kingdom, 80, 139-146.

Hoek, C. van den, 1987. The possible significance of long-range dispersal for the biogeography of seaweeds. Helgoländer Meeresuntersuchungen, 41, 261-272.

Koppelmann, R., 1994. Distribution and composition of gelatinous detrital material from closing net hauls in the north-east Atlantic. Marine Biology, 118, 755-759.

Santos, V., Billett, D.S.M., Rice, A.L. \& Wolff, G.A., 1994. Organic-matter in deep-sea sediments from the Porcupine Abyssal Plain in the northeast Atlantic Ocean. 1. Lipids. DeepSea Research, 41, 787-819.

Sargent, J.R. \& Falk-Petersen, S., 1981. Ecological investigations on the zooplankton community in Balsfjorden, northern Norway: lipids and fatty acids in Meganictiphanes norvegica, Thysanoessa raschi and T. inermis during mid-winter. Marine Biology, 62, 131-137.

Sargent, J.R., Henderson, R.J. \& Tocher, D.R., 1993. The lipids. In Biological chemistry of marine copepods (ed. E.D.S. Corner and S. O'Hara), pp. 59-108. Oxford: Oxford University Press.

Woelkerling, W.J., 1975. On the biotic and pelagic Chlorophyceae, Phaeopyceae, and Rhodophyceae of the western Sargasso Sea. Rhodora, 77, 1-40.

Submitted 5 January 2001. Accepted 11 February 2002 